\title{
Response of Cell Division and Cell Expansion to Local Fruit Heating in Tomato Fruit
}

\author{
Julienne Fanwoua ${ }^{1}$ \\ Wageningen UR Greenhouse Horticulture, P.O. Box 644, 6700 AP Wageningen, The Netherlands; \\ Horticultural Supply Chains, Wageningen University, P.O. Box 630, 6700 AP Wageningen, \\ The Netherlands; and the Centre for Crop Systems Analysis, Wageningen University, \\ P.O. Box 430, 6700 AK Wageningen, The Netherlands
}

Pieter de Visser

Wageningen UR Greenhouse Horticulture, P.O. Box 644, 6700 AP Wageningen, The Netherlands

Ep Heuvelink

Horticultural Supply Chains, Wageningen University, P.O. Box 630, 6700 AP Wageningen,

The Netherlands

\section{Gerco Angenent}

Plant Research International, Business Unit Bioscience, P.O. Box 16, 6700 AA Wageningen,

The Netherlands; and the Centre for BioSystems Genomics (CBSG), P.O. Box 16, 6700 AA

Wageningen, The Netherlands

Xinyou Yin

Centre for Crop Systems Analysis, Wageningen University, P.O. Box 430, 6700 AK Wageningen, The Netherlands

Leo Marcelis

Wageningen UR Greenhouse Horticulture, P.O. Box 644, 6700 AP Wageningen, The Netherlands; and Horticultural Supply Chains, Wageningen University, P.O. Box 630, 6700 AP Wageningen,

The Netherlands

Paul Struik

Centre for Crop Systems Analysis, Wageningen University, P.O. Box 430, 6700 AK Wageningen, The Netherlands

\begin{abstract}
AdDitional KeY words. fruit temperature, Solanum lycopersicum, fruit size, histology, periclinal cell expansion, anticlinal cell expansion

Abstract. To improve our understanding of fruit growth responses to temperature, it is important to analyze temperature effects on underlying fruit cellular processes. This study aimed at analyzing the response of tomato (Solanum lycopersicum) fruit size to heating as affected by changes in cell number and cell expansion in different directions. Individual trusses were enclosed into cuvettes and heating was applied either only during the first 7 days after anthesis (DAA), from 7 DAA until fruit maturity (breaker stage), or both. Fruit size and histological characteristics in the pericarp were measured. Heating fruit shortened fruit growth period and reduced final fruit size. Reduction in final fruit size of early-heated fruit was mainly associated with reduction in final pericarp cell volume. Early heating increased the number of cell layers in the pericarp but did not affect the total number of pericarp cells. These results indicate that in the tomato pericarp, periclinal cell divisions respond differently to temperature than anticlinal or randomly oriented cell divisions. Late heating only decreased pericarp thickness significantly. Continuously heating fruit reduced anticlinal cell expansion (direction perpendicular to fruit skin) more than periclinal cell expansion (direction parallel to fruit skin). This study emphasizes the need to measure cell expansion in more than one dimension in histological studies of fruit.
\end{abstract}

Fruit growth is strongly influenced by temperature. A shorter fruit growth period as a result of an increase in temperature has been reported in several plant species including kiwi [Actinidia deliciosa (Greer et al., 2003)], apricot [Prunus armeniaca (Jackson and Coombe, 1966)], cucumber [Cucumis sativus

Received for publication 9 May 2012. Accepted for publication 12 July 2012. ${ }^{1}$ Corresponding author. E-mail: julienne.fanwoua@wur.nl.
(Marcelis and Baan Hofman-Eijer, 1993)], and tomato (De Koning, 1994). Temperature also has a direct effect on the rate of fruit growth (Van der Ploeg and Heuvelink, 2005). In general no fruit growth is expected below a certain temperature threshold (Van der Ploeg and Heuvelink, 2005), estimated to be $5.7^{\circ} \mathrm{C}$ in tomato (Adams et al., 2001). Above this base temperature and below the optimum temperature threshold of $30^{\circ} \mathrm{C}$ (Pearce et al., 1993), increase in air temperature increases 
fruit growth rate, but final fruit size might be decreased (Adams et al., 2001; Sawhney and Polowick, 1985) or unaffected (Bertin, 2005; Van der Ploeg and Heuvelink, 2005) as a result of a shorter fruit growth period. Air temperature may also influence fruit growth indirectly through other plant growth and development processes (Adams et al., 2001; Bertin, 2005). For example, within a certain temperature range, an increase in air temperature is associated with an increase in the rate of plant development resulting in more sink organs formed by the plant (De Koning, 1994). This creates a stronger competition among individual sinks for assimilates, sometimes leading to abortion of flowers or incipient fruit (De Koning, 1989; Van der Ploeg and Heuvelink, 2005; Wubs et al., 2009).

When whole plants are exposed to various temperatures, indirect temperature effects make it impossible to quantify the extent to which temperature directly affects fruit growth. To overcome this limitation it is important to apply temperature treatments locally at the fruit level (Adams et al., 2001; Gautier et al., 2005). So far most studies have investigated the effects of whole plant temperatures on fruit growth (Bertin, 2005; De Koning, 1994), probably because of the technical challenges involved in implementing local temperature treatments. Adams et al. (2001) observed that heating individual tomato trusses from $15^{\circ} \mathrm{C}$ to 20 and $25^{\circ} \mathrm{C}$ in transparent chambers increased absolute fruit growth rate, but this effect was compensated by a reduced growth duration resulting in no significant temperature effects on the final fruit size. By contrast Gautier et al. (2005) found that fruit heating from $18.5 / 15.5$ to $21 / 18.4^{\circ} \mathrm{C}$ day/ night reduced tomato fruit size with more pronounced effects under limited assimilate supply. Marcelis and Baan HofmanEijer (1993) also showed that heating individual cucumber fruit from 17.5 to $27.5{ }^{\circ} \mathrm{C}$ reduced their final size when fruit were grown under limited assimilate supply.

Experimental data showed that the sensitivity of fruit growth to temperature is not the same during the whole fruit growth period in many plant species including cucumber (Marcelis and Baan Hofman-Eijer, 1993), apple [Malus domestica (Calderón-Zavala et al., 2004)], and tomato (De Koning, 2000). For instance, tomato fruit size and time to maturity were reduced when fruit were heated during the first 3 weeks after anthesis but were unaffected when heating was applied 1 or 2 weeks later (Adams et al., 2001). This difference in fruit sensitivity to temperature is not surprising considering that different processes are successively involved during the growth of a fruit (Gillaspy et al., 1993). During the first 7 to $10 \mathrm{~d}$ after anthesis, fruit growth in tomato is mainly the consequence of cell division. As cell division progressively stops, individual cells expand until the fruit reaches its final size (Bohner and Bangerth, 1988). To improve our understanding of fruit growth responses to temperature, it is important to analyze temperature effects on underlying fruit cellular processes.

Many studies described the effects of temperature on fruit growth at the fruit level (De Koning, 1994; Greer et al., 2003) but more rarely at the cell level (Bertin, 2005; Marcelis and Baan Hofman-Eijer, 1993). Increasing air temperature reduced cell number and increased cell sizes in tomato fruit as a result of a reduced cell division period and extended cell expansion period (Bertin, 2005). The author applied temperature treatments on whole plants and local temperature responses were not measured. In cucumber, increasing local fruit temperature reduced cell number but did not affect cell size when fruit were grown under limited assimilate supply (Marcelis and Baan Hofman-Eijer, 1993). Other experiments suggest that temperature effects on cell expansion might not be the same in all expansion directions (Erwin et al., 1991; Strøm and Moe, 1997). These experiments were carried out on plant stems and leaves (Erwin et al., 1991; Strøm and Moe, 1997). To the best of our knowledge, no studies on the effects of temperature on cell expansion in different expansion directions have been reported in fruit tissue.

This study investigates the response of tomato fruit growth to local temperature applied early or late during fruit growth. The objectives were first to analyze whether the reduction in final fruit size of early- or late-heated fruit is related to reduction in cell number or cell size and, second, to investigate temperature effects on fruit cell expansion in different expansion directions.

\section{Materials and Methods}

\section{Plant material and growth conditions}

Two experiments were conducted in 2010 (Expt. 1) and 2009 (Expt. 2) to study the effects of local heating on the growth of tomato fruit. In both experiments, seedlings of tomato (cv. Moneyberg) were grown for 8 weeks (Expt. 1: Jan. to Feb. 2010, Expt. 2: Nov. to Dec. 2009) and then transplanted in the greenhouse on stonewool slabs at a density of 2.5 plants $/ \mathrm{m}^{2}$. Nutrient solution was prepared according to De Kreij et al. (1997) and provided by fertigation (electrical conductivity 3.0 $\mathrm{dS} \cdot \mathrm{m}^{-1}, \mathrm{pH}$ 5.6). Climatic conditions in the greenhouse were ( \pm SE) $21.5 \pm 0.09^{\circ} \mathrm{C}$ (day) and $18.1 \pm 0.05^{\circ} \mathrm{C}$ (night) in Expt. 1 or $22.0 \pm 0.17{ }^{\circ} \mathrm{C}$ (day) and $18.5 \pm 0.10^{\circ} \mathrm{C}$ (night) in Expt. 2, 16-h photoperiod [0.6 to $28.4 \mathrm{MJ} \cdot \mathrm{m}^{-2} \cdot \mathrm{d}^{-1}$ natural light supplemented with artificial light using high-pressure sodium lamps (135 $\mu \mathrm{mol} \cdot \mathrm{m}^{-2} \cdot \mathrm{s}^{-1}$ photosynthetically active radiation; SON-T Agro; Philips, Eindhoven, The Netherlands)], and $400 \mu \mathrm{mol} \cdot \mathrm{mol}^{-1}$ $\mathrm{CO}_{2}$. Flowers were pollinated by vibrating each truss three times per week. All trusses on the plants were pruned to five fruit. Side shoots were removed once per week.

\section{Heating system}

Individual trusses were heated into small cuvettes constructed from Perspex (WSV Kunststoffen, Utrecht, The Netherlands) (Fig. 1A). Each heating cuvette consisted of a cylindrical chamber (13 cm diameter and $20 \mathrm{~cm}$ long) equipped with an electronic heating unit (Conrad Electronic, Hirschau, Germany) and a fan (1004KL-04W-B40-B00; NMB-Minebea, Chatsworth, CA) at the base of the chamber blew air into the chamber and released it through an outlet at the top. The maximum flow rate of the fan was $40 \mathrm{~L} \cdot \mathrm{min}^{-1}$. Sensors (Conrad Electronic) continually monitored air temperature inside and outside the chamber. The heating unit was calibrated to control the functioning of the heating block (Cirrus 25; DBK, Spartanburg, SC) and to regulate the temperature of the air inside the chamber. The realized air temperature inside the chamber was ( \pm SE) $26.9 \pm 0.12{ }^{\circ} \mathrm{C}$ (day) and $22.7 \pm 0.10{ }^{\circ} \mathrm{C}$ (night) in Expt. 1 or $27.0 \pm 0.44{ }^{\circ} \mathrm{C}$ (day) and $23.0 \pm 0.20^{\circ} \mathrm{C}$ (night) in Expt. 2. When cuvettes were used for the control treatment, the heating unit was switched off, but not the fan, and the temperature inside the chamber was the same as the temperature outside.

\section{Experimental design and treatments}

Heating treatments were implemented 10 weeks after transplanting. For each plant at this stage the truss of which the second proximal flower was at anthesis was selected to receive one of the treatments and was enclosed into the cuvette. All other trusses on the plant were not enclosed into a cuvette. 
(A)

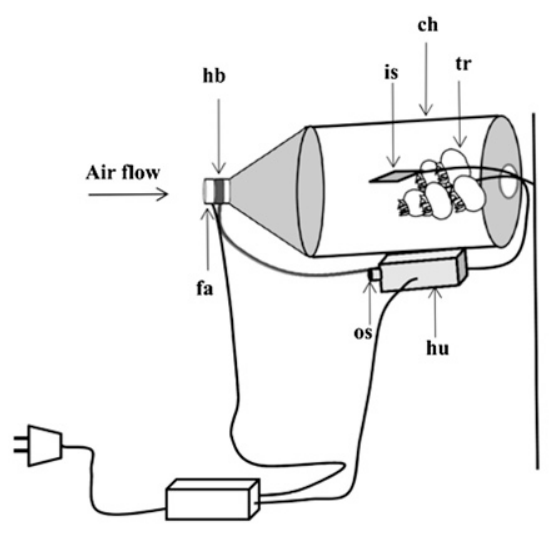

(B)

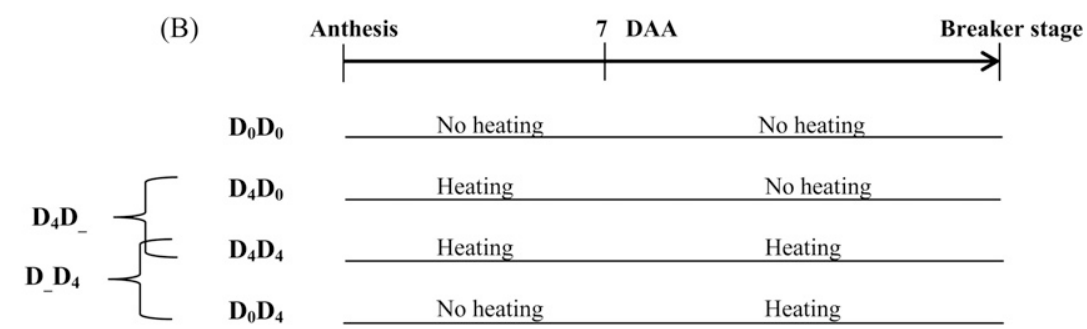

Fig. 1. (A) Schematic representation of the heating system $(\mathrm{hb}=$ heating block; is = inside temperature sensor; $\mathrm{ch}=$ chamber; $\operatorname{tr}=$ tomato truss; $\mathrm{hu}=$ heating unit; os $=$ outside temperature sensor; $\mathrm{fa}=$ fan). (B) Scheme of tomato fruit heating treatments in Expt. 2: in $\mathrm{D}_{0} \mathrm{D}_{0}$ treatment, fruit were not heated from anthesis until breaker stage; in $\mathrm{D}_{4} \mathrm{D}_{0}$, fruit were heated from anthesis until $7 \mathrm{~d}$ after anthesis (DAA) and not heated from 7 DAA until the breaker stage; in $\mathrm{D}_{4} \mathrm{D}_{4}$, fruit were heated from anthesis until the breaker stage; in $\mathrm{D}_{0} \mathrm{D}_{4}$, fruit were not heated from anthesis until 7 DAA and heated from 7 DAA until the breaker stage.

In Expt. 1, treatments were applied to investigate the effects of continuous local heating on fruit growth. In the heating treatment, trusses were heated continuously until the breaker stage of the second proximal fruit, which was reached 46 DAA. In the control treatment, trusses were also enclosed into cuvettes until the breaker stage of the second proximal fruit, which was reached 54 DAA.

In Expt. 2, treatments were applied to investigate the effects of local heating at two different stages of fruit growth on final fruit phenotype. We studied the effects of heating fruit during the first 7 DAA, the effects of heating fruit from 7 DAA until fruit maturation, and the interaction between these two heating schemes. In the interaction, we tested whether the effects of fruit heating applied during the first 7 DAA on a response variable were affected by the heating treatment applied from 7 DAA until the breaker stage. Four treatments were applied as described in Figure 1B.

Treatments were applied to experimental units, each of which consisted of six plants (Expt. 1) or one plant (Expt. 2). Experimental units were arranged according to a completely randomized design with five replicates.

\section{Observations and measurements}

Flower AND FRUIT MEASUREMENTS. In each experimental unit, observations and measurements were carried out on one fruit located at the second proximal position of the selected truss. For all selected trusses, observations of anthesis were recorded before trusses were enclosed into the cuvettes. Anthesis was considered as the first day on which a flower opens fully. In Expt. 1, the second proximal fruit in each selected truss was harvested at a specific thermal time [calculated as the temperature sum above a base temperature of $5.7{ }^{\circ} \mathrm{C}$ (Adams et al., 2001)]; i.e., 0, 69, 129, 232, and $374{ }^{\circ} \mathrm{C}$ DAA, and at the breaker stage (reached at $881^{\circ} \mathrm{C} \mathrm{DAA}$ ). This corresponded to $0,2,5,11,18$, and $46 \mathrm{DAA}$, respectively, in the heating treatment, or to $0,3,7,15,25$, and 54 DAA, respectively, in the control treatment. In Expt. 2, the second proximal fruit in all cuvettes was harvested at the breaker stage, which was reached at $853^{\circ} \mathrm{C}$ DAA, and corresponded to 55, 52, 46, and 45 DAA in the D0D0, D4D0, D0D4, and D4D4 treatments, respectively (Fig. 1B).

Harvested fruit were weighed and their diameters in the horizontal plane measured using a digital calliper (Schneider-klein; Sukiinternational, Landscheid, Germany). Average fruit diameter was calculated after estimating fruit diameter in the vertical direction calculated from the relationship between fruit diameter in the vertical and horizontal directions estimated in 'Moneyberg' $(\mathrm{N}=58)$ (Fig. S1). Each harvested fruit was split into two halves at the equatorial plane; the pericarp was isolated and used for cell histology.

Cell histology. For each harvested fruit, four pericarp samples were fixed overnight at room temperature in a 1 acetic acid: 2 formaldehyde:5 ethanol solution. Sections of $3 \mu \mathrm{m}$ thick were stained using toluidine blue and photographed on a light microscope (Eclipse 50i; Nikon Instruments Europe, Kingston, U.K.) equipped with a color digital camera. Images were analyzed with Image $\mathrm{J}$ (National Institutes of Health, Bethesda, MD). During image analysis two tissues were distinguished in each pericarp section: the first five cell layers (including the cuticle) representing the exocarp and the region between the fifth cell layer and the endocarp representing the mesocarp (Fig. 2A). To determine cell area, a rectangle was drawn in each tissue centered in the area containing no vascular bundle (Fig. 2A). Vascular bundles and endocarp cells were excluded from the measurements because they do not contribute much to pericarp size. The mean pericarp cell area in each tissue was determined as the ratio between the area of the rectangle and the number of cells inside the rectangle. The mean cell area in each tissue was used to estimate mean cell volume assuming that tomato cells have an ellipsoid shape (Fig. 2B).

$$
C_{v o l, T}=\frac{4}{3} 0.5 C_{a, T} D_{T}
$$

where subscript $T$ refers to the measured tissue (i.e., the exocarp or mesocarp), $C_{v o l, T}$ is the average cell volume (in cubic millimeters) in the exocarp or mesocarp, $C_{a, T}$ is the average cell area in the exocarp or mesocarp (in square millimeters), and $D_{T}$ is the cell width in the third dimension of the ellipsoid (Fig. 2B) calculated according to the formula: 
A)

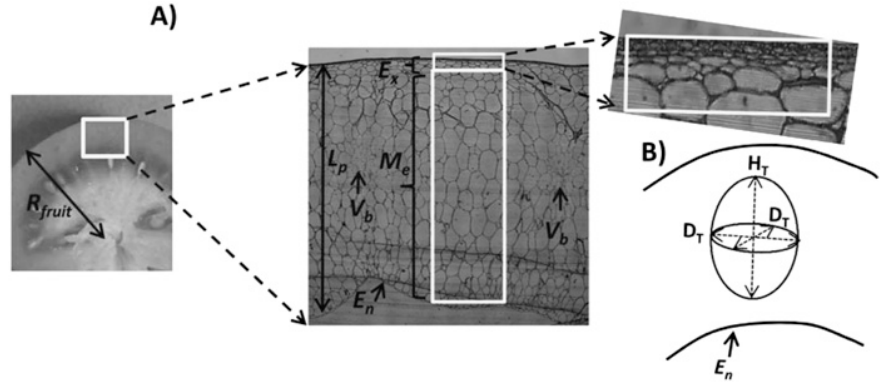

Fig. 2. Structure of tomato pericarp at the breaker stage: (A) white rectangles are examples of the region within which mean cell area was estimated in the exocarp and mesocarp as detailed in the materials and methods; (B) schematic representation of the ellipsoid cell shape in the pericarp $\left\{R_{\text {fruit }}=\right.$ fruit radius; $L_{p}=$ pericarp thickness; $V_{b}=$ vascular bundle; $E_{x}=$ exocarp; $M_{e}=$ mesocarp; $E_{n}=$ endocarp; $\mathrm{H}_{\mathrm{T}}=$ cell length [anticlinal direction (i.e., perpendicular to the fruit skin)]; $\mathrm{D}_{\mathrm{T}}$ is cell width [periclinal direction (i.e., parallel to the fruit skin)] .

$$
D_{T}=\frac{C_{a, T}}{0.25 \pi H_{T}}
$$

where $H_{T}$ is the average cell length [in the anticlinal direction (i.e., perpendicular to the fruit skin)] in the exocarp or mesocarp (in millimeters) (Fig. 2B). $H_{T}$ was calculated by dividing the tissue thickness by its number of cell layers, $\pi=3.14$. Eq. [2] assumes that cell width [in the periclinal direction (i.e., parallel to fruit skin)] in the two-dimensional plane equals cell width in the third dimension of the ellipsoid. To control this assumption, we sectioned some pericarps in the longitudinal and transversal directions and analyzed cell length and width differences in both directions. Cell width in both directions was not statistically different (data not shown).

The average cell volume of the pericarp was calculated as the weighted average of cell volume in the exocarp and mesocarp.

The number of cells in the exocarp or mesocarp tissue $\left(C_{n}, T\right)$ was calculated by dividing the exocarp or mesocarp tissue volume, $P_{\text {vol, } T}$, by the mean tissue cell volume, $C_{\text {vol, } T}$ :

$$
C_{n, T}=\frac{P_{v o l, T}}{C_{v o l, T}}
$$

where $P_{v o l, T}$ (in cubic millimeters) is calculated approximating the tomato fruit to a sphere. In case of exocarp, the formula for $P_{\text {vol, }, T}$ is:

$$
P_{\mathrm{vol}, \mathrm{T}}=\frac{4}{3} \pi\left[R_{\text {fruit }}^{3}-\left(R_{\text {fruit }}-L_{\mathrm{E}}\right)^{3}\right]
$$

where $R_{\text {fruit }}$ is the fruit radius (in millimeters) and $L_{E}$ is the exocarp thickness (in millimeters). Then $P_{v o l}, T$ for mesocarp is expressed as:

$$
P_{\mathrm{vol}, \mathrm{T}}=P_{\mathrm{vol}}-\frac{4}{3} \pi\left[R_{\text {fruit }}^{3}-\left(R_{\text {fruit }}-L_{\mathrm{E}}\right)^{3}\right]
$$

where $P_{v o l}$ is the pericarp volume (in cubic millimeters), which was calculated as:

$$
P_{\mathrm{vol}}=\frac{4}{3} \pi\left[R_{\text {fruit }}^{3}-\left(R_{\text {fruit }}-L_{\mathrm{P}}\right)^{3}\right]
$$

where $L_{P}$ is the pericarp thickness (in millimeters).
Statistical AnALysis. The effects of heating treatments on variables measured on fruit at the same growth stage were analyzed by analysis of variance and F-tests were used to determine the statistical significance (Matlab; The Mathworks, Natick, MA). The relationships among fruit fresh weight, pericarp volume, cell number, and cell volume were analyzed using linear regression. The coefficient of determination and the statistical significance of the simple linear regression were used to assess the quality of the relationships.

\section{Results}

EFFECTS OF CONTINUOUS HEATING ON FRUIT AND CELL CHARACTERISTICS DURING FRUIT GROWTH. Continuous heating significantly reduced final fruit fresh weight $(P=0.002)$, fruit diameter $(P=0.004)$, and fruit volume $(P=0.003)$ in Expt. 1 . In Expt. 2, final fruit size of continuously heated fruit was also reduced $(P=0.02)$, but the effects were less pronounced than in Expt. 1 (Fig. 3A-B). The time course of fruit growth measured in Expt. 1 showed that reduction in final fruit size was mainly accounted for by the effect of heating on fruit growth duration. Heating initially increased fruit growth rate (Figs. S2A and 3A), but this increase was more than compensated for by a drastic reduction in fruit growth duration of $8 \pm 1.6 \mathrm{~d}(P=0.010)$ in the heating treatment compared with the control (Fig. S2A). When fruit size was plotted against temperature sum, final fruit size was reached at approximately the same temperature sum $\left(881 \pm 17^{\circ} \mathrm{Cd}\right)$ in heated and non-heated fruit (Fig. 3A-B). The time course of pericarp volume growth responded similarly to continuous fruit heating as fruit fresh weight (Fig. 3C). Final pericarp volume was reduced by $36 \%$ (Expt. 1) or 26\% (Expt. 2) in heated fruit. In contrast, fruit heating did not significantly affect final pericarp thickness $(P=0.18)$, although during fruit growth, increase in pericarp thickness started earlier in the heating treatment compared with the control (Figs. S2D and 3D). At the same temperature sum, pericarp thickness was similar in heated and non-heated fruit except at $232{ }^{\circ} \mathrm{Cd}$ (Fig. 3D).

From anthesis until maturity cell, volume increased $\approx 11,000$-fold in both heated and non-heated fruit. Continuously heating the fruit significantly reduced their final pericarp cell volume in Expt. 2 (Figs. S3A and 4A). In Expt. 1, increase in cell volume started earlier in heated fruit compared with nonheated fruit (Figs. S3A and 4A), but this did not result in significant differences in final volume of pericarp cells $(P=0.79)$. A similar pattern was observed with exocarp and mesocarp cells where heating treatment did not significantly affect their final volume either $(P>0.65$; data not shown). Interestingly, although heating did not affect final pericarp cell volume in Expt. 1, its effect was not the same in all cell expansion directions. At $232{ }^{\circ} \mathrm{Cd}$, cell length was larger in heated fruit than in non-heated fruit $(P=$ 0.003; Fig. 4B). After this point, cell expansion in the anticlinal direction (i.e., increase in cell length) was faster in non-heated fruit than in heated fruit $\left[P=0.07\right.$ at $374{ }^{\circ} \mathrm{Cd}$ (Fig. 4B)] leading to a significant reduction in final cell length in heated fruit compared with non-heated fruit $(P=0.001)$. The effects of heating on periclinal cell expansion (i.e., increase in cell width) did not result in significant differences in final pericarp cell width $(P=0.35)$.

The generation of new cell layers occurred from anthesis onward at a similar rate in heated and non-heated fruit (Fig. 4D). In non-heated fruit, the maximum number of cell layers was reached at $129{ }^{\circ} \mathrm{Cd}$. However, new cell layers continued to be formed up to $232{ }^{\circ} \mathrm{Cd}$ in heated fruit (Fig. 4D), which led 

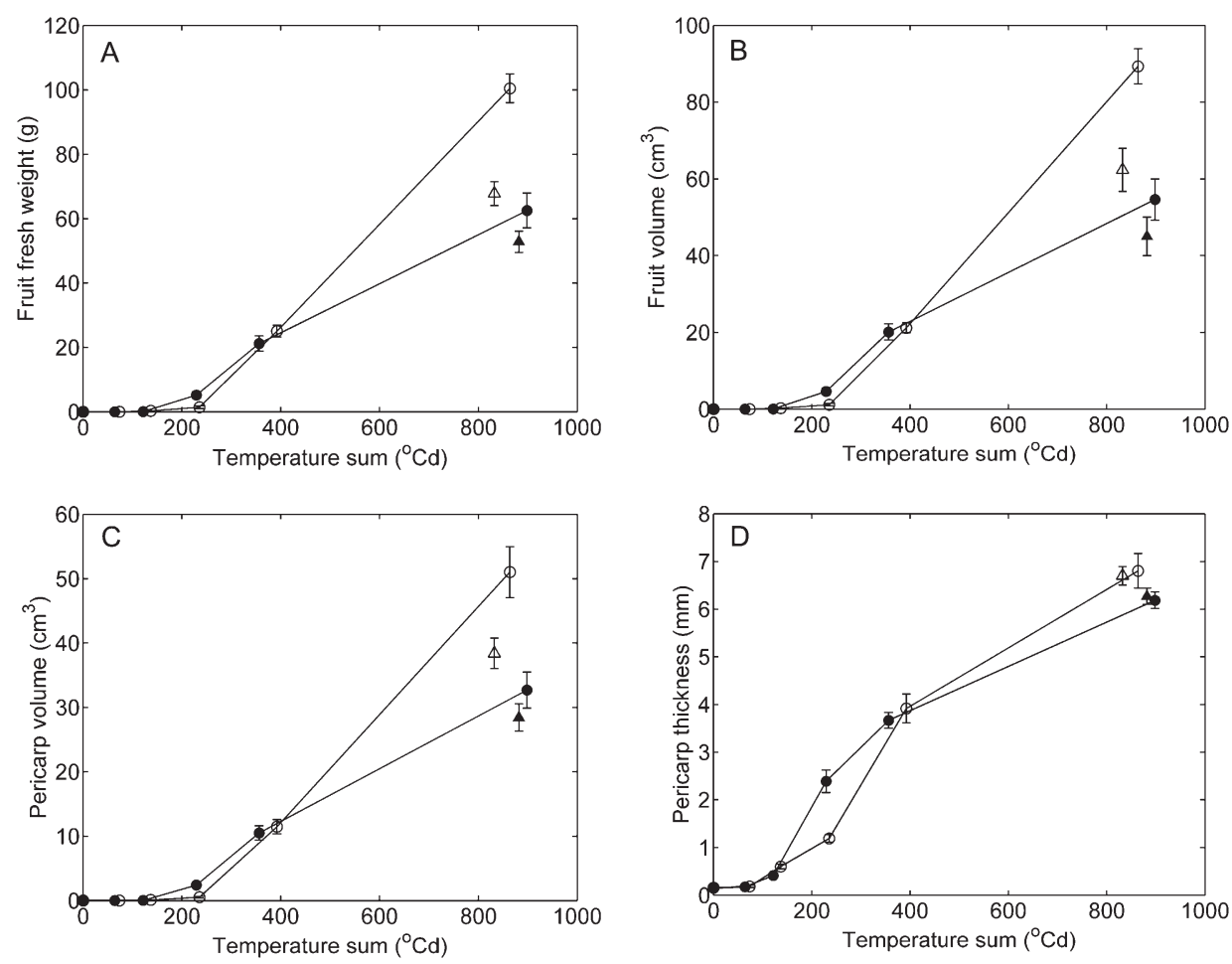

Fig. 3. Time course of (A) tomato fruit fresh weight, (B) fruit volume, (C) pericarp volume, and (D) pericarp thickness during fruit growth [Expt. 1 (circles)]. Each point is the mean ( $\pm \mathrm{SE})$ of three to five replicate fruit heated continuously (closed symbols) or non-heated (open symbols). The last data points were measured from fruit at the breaker stage, at which data were also available from Expt. 2 (triangles) and were presented for comparison between the two experiments.

to significantly more cell layers in matured heated fruit compared with non-heated fruit $(P=0.01)$. In Expt. 2 the increase in the final number of cell layers in continuously heated fruit was less pronounced than in Expt. 1.

Cell division occurred at a higher rate in the pericarp of nonheated fruit compared with heated fruit (Figs. S3E and 4E). In both treatments no more cells were produced after $232^{\circ} \mathrm{Cd}$ (Fig. 4E). Matured heated fruit had $3.8( \pm 0.66) \times 10^{6}$ (Expt. 1) or $2.8( \pm 0.22) \times 10^{6}($ Expt. 2$)$ cells compared with $4.8( \pm 0.34) \times$ $10^{6}$ (Expt. 1) or $3.1( \pm 0.25) \times 10^{6}$ (Expt. 2) cells in non-heated fruit.

EFFECTS OF HEATING APPLIED DURING THE FIRST 7 DAYS AFTER ANTHESIS AND FROM 7 DAYS AFTER ANTHESIS ONWARD ON FINAL FRUIT CHARACTERISTICS. For all fruit and cell characteristics measured, no interaction was detected between heating during the first 7 DAA and heating from 7 DAA onward. Therefore, main effects were tested. Heating fruit during the first 7 DAA reduced final fruit fresh weight by $12 \%$, fruit volume by $21 \%$, and pericarp volume by $16 \%$ compared with the situation in which no heating was applied during the first $7 \mathrm{~d}$ (Table 1). Heating fruit from 7 DAA onward had no significant effects on final fruit fresh weight, fruit volume, and pericarp volume $(P>$ 0.07).

Final pericarp thickness was unaffected by early heating but was statistically significantly reduced by $8 \%$ when fruit were heated from 7 DAA onward (Table 1). Early heating significantly increased the number of cell layers but not the total number of cells in the pericarp (Table 1). Heating fruit from 7 DAA onward did not affect the final number of cell layers nor the total number of cells (Table 1). Average pericarp cell volume was significantly decreased by $27 \%$ in fruit heated during the first 7 DAA (Table 1).

The effect of heating applied from 7 DAA onward on pericarp cell volume was not statistically significant (Table 1). Mesocarp cell volume responded similarly to heating treatments as average pericarp cell volume did (Table 1). The effects of heating treatments on final exocarp cell volume were not statistically significant (Table 1).

EFFECTS OF FRUIT HEATING ON THE CORRELATION BETWEEN FRUIT AND HISTOLOGICAL VARIABLES IN MATURE FRUIT. We investigated whether heating fruit during the first 7 DAA or from 7 DAA onward had an influence on the correlations between fruit and histological characteristics. We used simple linear regression to analyze the relationships among fruit weight, pericarp volume, pericarp cell number, and pericarp cell volume in different heating treatments. In all heating treatments, pericarp volume linearly correlated to fruit fresh weight (Fig. $5 \mathrm{~A})$. Regression analysis was carried out between pericarp volume and other histological traits. In none of the heating treatments was cell volume significantly correlated with pericarp volume $(P>0.25)$ (Fig. 5B). Positive correlations were noted between cell number and pericarp volume for fruit heated during the first 7 DAA $(P=0.01)$, but not for fruit heated from 7 DAA onward ( $P=0.07$; Fig. 5C). Negative correlation coefficients were found between cell number and cell volume for fruit heated during the first 7 DAA $(P=0.01)$, but not for fruit heated from 7 DAA onward $(P=0.16$; Fig. 5D).

\section{Discussion}

In agreement with the literature (De Koning, 1994; Gautier et al., 2005; Greer et al., 2003), continuous fruit heating in our experiments reduced fruit growth duration and final fruit size. Surprisingly, the effects of continuous heating on final fruit size were more pronounced in Expt. 1 than in Expt. 2 (Fig. 3A). Because fruit temperature was similar in both experiments, the reasons for this difference in the magnitude of effects remain unclear. In our experiments, we used moderate temperature range, far below the temperatures responsible for heat stress in tomato fruit (Pearce et al., 1993). We showed that in this temperature range, fruit size reduction was mostly the result of heating during the first week of fruit growth (Table 1). This result is consistent with the findings of Adams et al. (2001) and De Koning (1994) who observed that tomato fruit are more sensitive to heating applied during the first weeks of fruit growth than to heating applied later. Similar observations were reported by Marcelis and Baan Hofman-Eijer (1993) in cucumber fruit. 

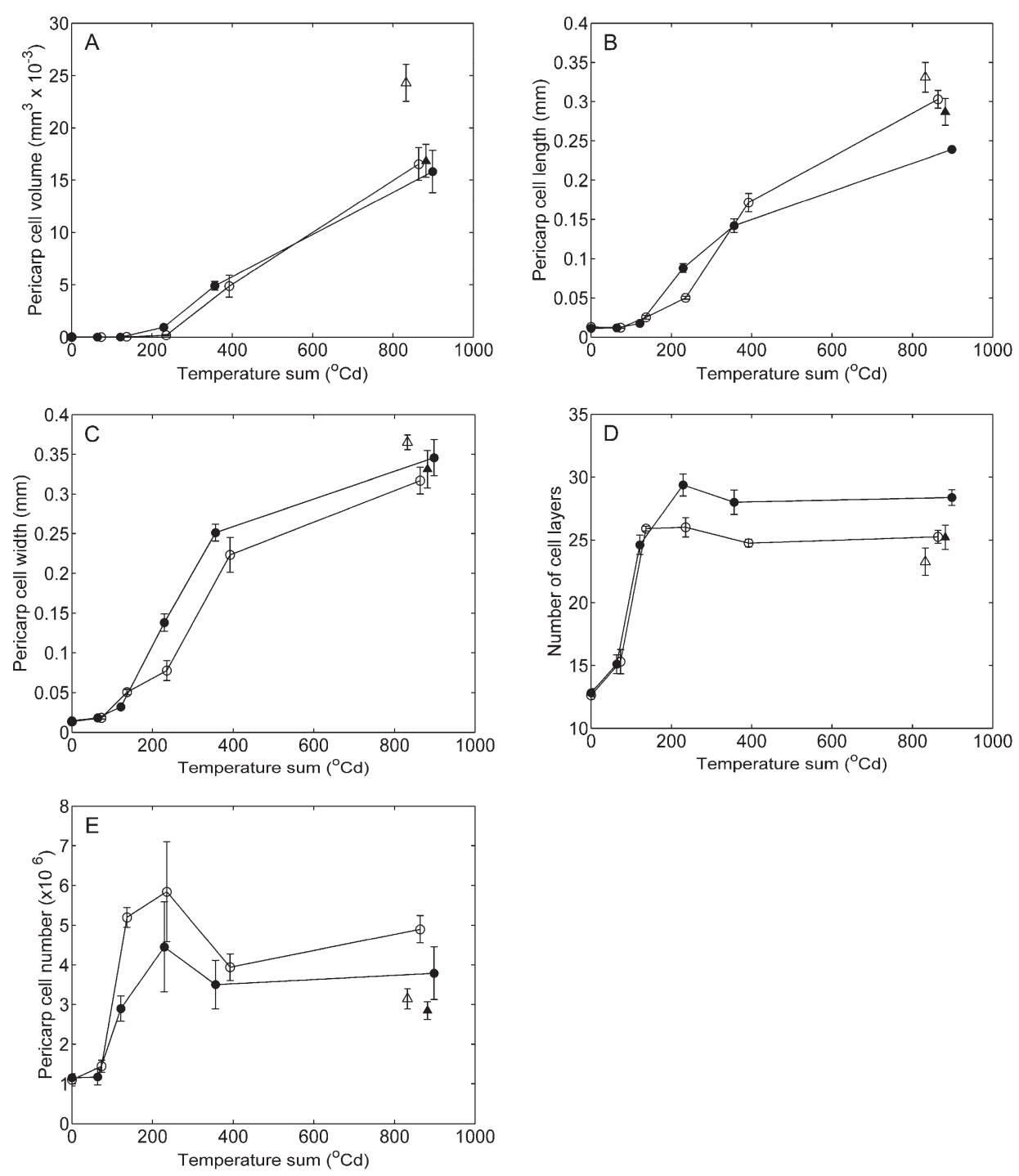

Fig. 4. Time course of (A) tomato fruit pericarp cell volume, $(\mathbf{B})$ pericarp cell length (anticlinal direction), (C) pericarp cell width (periclinal direction), (D) number of cell layers, and (E) pericarp cell number during fruit growth [Expt. 1 (circles)]. Each point is the mean $( \pm \mathrm{SE})$ of three to five replicate fruit heated continuously (closed symbols) or not heated continuously (open symbols). The last data points were measured from tomato fruit at the breaker stage, at which data were also available from Expt. 2 (triangles) and were presented for comparison between the two experiments.

The linear correlation found between fruit fresh weight and pericarp volume in all our heating treatments suggests that pericarp volume might be sufficient to describe variations in fruit fresh weight. In our experiment, final pericarp thickness was unaffected by heating treatments (Fig. 3D). Pericarp thickness is the consequence of two underlying cellular processes: cell expansion and the generation of new cell layers. The absence of heating effects on final pericarp thickness was the result of the opposite effects of heating on cell expansion and on cell layer generation.

The onset of cell expansion was advanced in heated fruit. This early cell expansion probably explains the initial increase in fruit growth rate observed in heated fruit in our experiment. Several authors reported an increase in the growth rate of young fruit exposed to high temperatures (Bertin, 2005; Marcelis and Baan Hofman-Eijer, 1993). Bertin (2005) observed that growing tomato plants under high temperatures $\left(25 / 25^{\circ} \mathrm{C}\right)$ advanced the onset of cell expansion in tomato fruit but did not alter cell expansion rate. In the same experiment, she reported that final cell volume was increased by high temperature (Bertin, 2005), which contrasts with our results in which final cell volume was either reduced [early heating or continuous heating (Expt. 2)] or not significantly affected [continuous heating (Expt. 1) or heating from 7 DAA onward] by heating treatments. This discrepancy might be linked to the low fruit assimilate supply in our experiments induced by high fruit load (five fruit/truss) compared with the high assimilate supply in Bertin's experiment induced by low fruit load (two fruit/ truss). Indeed, Gautier et al. (2005) showed that the effects of fruit heating were more pronounced when tomato fruit were grown under limited assimilate supply. In cucumber fruit, Marcelis and Baan Hofman-Eijer (1993) observed that high temperature increased final cell size when fruit were grown under non-limiting assimilate supply, but temperature did not affect final cell size when assimilate supply was limiting.

In our experiments, the effects of continuous fruit heating on final cell length were more pronounced than on cell width (Fig. 4B-C). This suggests that heating might not affect periclinal and anticlinal cell expansion in a similar way. In kidney bean (Phaseolus vulgaris) and soybean (Glycine max) stems, Ikeda et al. (1999) observed that cell elongation rates and durations were very different in the cell length and cell width directions. The direction of cell expansion in plants is mainly determined by the orientation of cellulose microtubules and microfibrils (Wasteneys and Ambroise, 2009). In the internode of pea (Pisum sativum) seedlings, Akashi and Shibaoka (1987) observed that transverse and longitudinal microtubules responded differently to low-temperature treatment and hormone application. Exposing potato (Solanum tuberosum) stolons to gibberellins resulted in the transversal orientation of cell microtubules and microfibrils (Prat, 2010). In tomato fruit, high temperatures are known to affect the production of plant hormones such as gibberellins (Sasaki et al., 2005) and could indirectly influence the orientation of cell microtubules and microfibrils and thus the orientation of cell expansion in our experiments. High temperature increased cell length but did not affect cell width in stems of Campanula isophylla (Strøm and Moe, 1997) and Lilium longiflorum (Erwin et al., 1991). These results together with our data underscore the need in histological studies to 
Table 1. Effects of fruit heating from anthesis until $7 \mathrm{~d}$ after anthesis $(\mathrm{DAA})\left(\mathrm{D}_{4} \mathrm{D}_{-}\right)$and of fruit heating from 7 DAA onward $\left(\mathrm{D}_{-} \mathrm{D}_{4}\right)$ on final tomato fruit and cell phenotypes. ${ }^{\mathrm{z}}$

\begin{tabular}{|c|c|c|c|c|c|c|}
\hline & \multicolumn{3}{|c|}{ Heating from anthesis until 7 DAA } & \multicolumn{3}{|c|}{ Heating from 7 DAA until maturity } \\
\hline & Not heated (D0D_) & Heated (D4D_) & $P$ value & Not heated (D_D0) & Heated (D_D4) & $P$ value \\
\hline Fruit fresh weight (g) & 64.2 & 56.2 & 0.05 & 63.7 & 56.7 & 0.09 \\
\hline Fruit volume $\left(\mathrm{cm}^{3}\right)$ & 61.2 & 48.3 & 0.01 & 57.0 & 52.5 & 0.28 \\
\hline Pericarp volume $\left(\mathrm{cm}^{3}\right)$ & 36.6 & 30.7 & 0.01 & 35.7 & 31.6 & 0.08 \\
\hline Pericarp thickness (mm) & 6.4 & 6.5 & 0.77 & 6.7 & 6.2 & 0.02 \\
\hline Number of cell layers & 23.8 & 26.1 & 0.02 & 25.1 & 24.8 & 0.70 \\
\hline Average cell volume $\left(\times 10^{-3} \mathrm{~mm}^{3}\right)$ & 22.3 & 16.3 & 0.02 & 20.0 & 18.5 & 0.54 \\
\hline Cell volume exocarp $\left(\times 10^{-3} \mathrm{~mm}^{3}\right)$ & 1.6 & 1.5 & 0.68 & 1.6 & 1.5 & 0.81 \\
\hline Cell volume mesocarp $\left(\times 10^{-3} \mathrm{~mm}^{3}\right)$ & 23.6 & 17.1 & 0.02 & 21.2 & 19.6 & 0.54 \\
\hline Cell number $\left(\times 10^{6}\right)$ & 3.21 & 3.19 & 0.96 & 3.34 & 3.06 & 0.51 \\
\hline Pericarp cell width (mm) & 0.36 & 0.33 & 0.17 & 0.34 & 0.34 & 0.99 \\
\hline Pericarp cell length (mm) & 0.31 & 0.28 & 0.07 & 0.30 & 0.29 & 0.19 \\
\hline
\end{tabular}

In the D0D_treatment, fruit were not heated from anthesis until 7 DAA; in the D_D0 treatment, fruit were not heated from 7 DAA until breaker stage. Each value is the mean of eight to 10 replicate fruit (Expt. 2). ${ }^{y}$

${ }^{y}$ For all response variables measured, no significant interaction was observed between the effects of heating from anthesis until 7 DAA and heating from 7 DAA until the breaker stage.
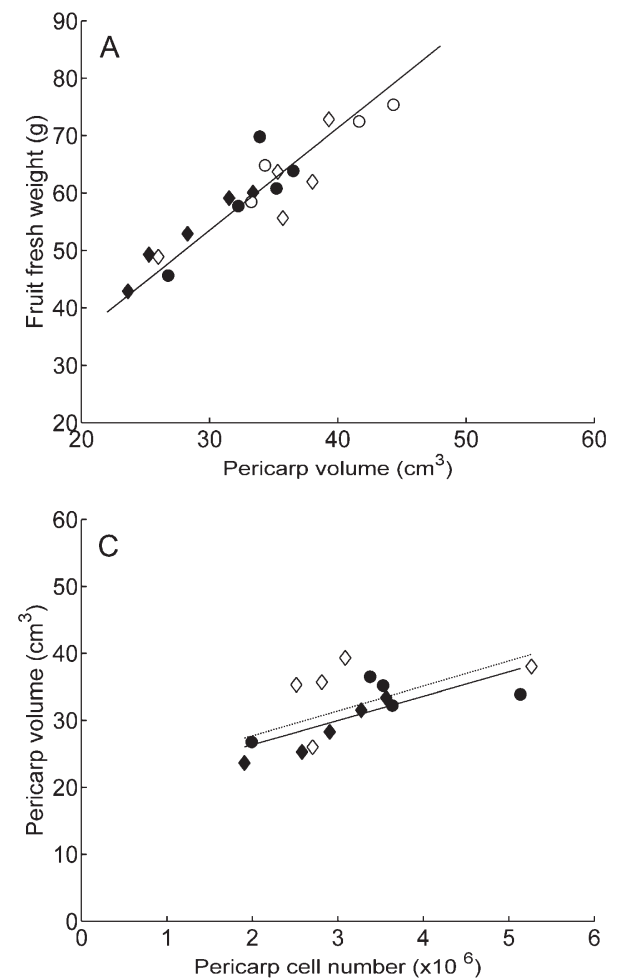
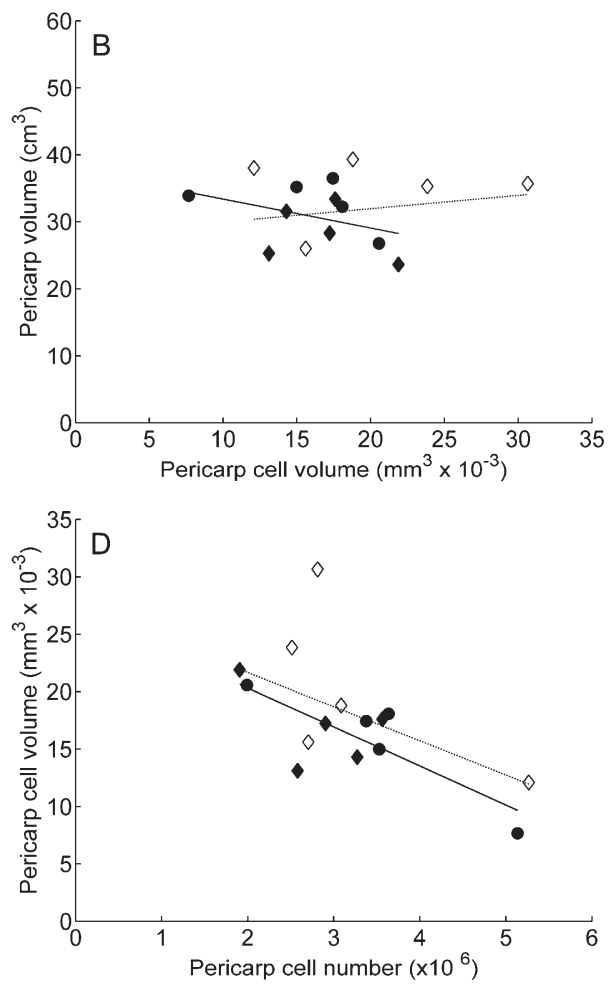

Fig. 5. Correlations between (A) tomato fruit fresh weight and pericarp volume, (B) pericarp volume and pericarp cell volume, $(\mathbf{C})$ pericarp volume and pericarp cell number, and (D) pericarp cell volume and pericarp cell number. Regression in $\mathbf{A}$ is fitted overall data points. Each point is an individual fruit at the breaker stage of fruit heated from anthesis to $7 \mathrm{~d}$ after anthesis (DAA) [D4D_ (closed symbols and solid line)], fruit heated from 7 DAA until maturity [D_D4 (diamond and dotted line)] and fruit not heated from anthesis until maturity $\left[\mathrm{D}_{0} \mathrm{D}_{0}\right.$ (open circles)]. The slope $(\alpha)$ of regression is $(\mathbf{A}) \alpha=1.8 \mathrm{~g} \cdot \mathrm{cm}^{-3}, R^{2}=0.82, P<0.001$; (B) $\alpha=-0.43 \mathrm{~cm}^{3} \cdot \mathrm{mm}^{-3}$, $R^{2}=0.16, P=0.26$ (D4D_), and $\alpha=0.20 \mathrm{~cm}^{3} \cdot \mathrm{mm}^{-3}, R^{2}=0.04, P=0.58$ (D_D4); (C) $\alpha=3.63 \mathrm{~cm}^{3}, R^{2}=0.59, P=$ 0.01 (D4D_), and $\alpha=3.72 \mathrm{~cm}^{3}, R^{2}=0.36, P=0.07$ (D_D4); (D) $\alpha=-3.39 \mathrm{~mm}^{3}, R^{2}=0.61, P=0.01$ (D4D_) and $\alpha=-2.97 \mathrm{~mm}^{3}, R^{2}=0.22, P=0.17$ (D_D4).

measure cell expansion in more than one dimension to reflect the dynamics of cell expansion in plant organs.

In our experiments the final number of cell layers was increased in heated fruit. The formation of new cell layers in tomato pericarp mainly occurs early in fruit growth (Fig. 4D;
Cheniclet et al., 2005) and, as expected, the final number of cell layers in our experiment was sensitive to heating applied during the first week of fruit growth (Table 1). The number of cell layers in the pericarp is an indication of periclinal cell division (i.e., division plane parallel to fruit skin) activity (Cheniclet et al., 2005). Our results suggest that heating prolonged periclinal cell division as new cell layers continued to be generated until $232{ }^{\circ} \mathrm{Cd}$ in heated fruit compared with $129{ }^{\circ} \mathrm{Cd}$ in non-heated fruit. In a tomato fruit, the total number of cells in the pericarp results not only from periclinal cell divisions, but also from anticlinal cell divisions (i.e., division plane perpendicular to fruit skin) and randomly oriented cell divisions (Cheniclet et al., 2005). With increasing fruit temperature, a decrease in cell division period and final fruit cell number is usually found (Bertin, 2005; Marcelis and Baan HofmanEijer, 1993). Continuous fruit heating also shortened the cell division period in our experiment (Fig. S3E), but not to the extent that reduction in final cell number was statistically significant. Early heating had no effect on final pericarp cell number (Table 1). This might be because in our experiment, early heating was applied only during the first week of fruit growth. During this period, heating mainly affected periclinal cell division, which occurs during the first week of fruit growth, whereas anticlinal and randomly oriented cell division continued for a longer period in the pericarp. A longer heating period early in fruit growth would probably affect all types of cell 
division in the pericarp and final cell number. In this study, final fruit size reduction of early-heated fruit was not related to the reduction in cell number, but to the reduction in final cell volume (Table 1).

In contrast, with the duration of cell layer production that was prolonged in continuously heated fruit, we observed that the duration of cell division in the whole pericarp was shortened by continuous heating (Fig. S3E). These contrasting effects suggest that periclinal cell division and other types of cell divisions might respond differently to temperature and might be regulated differently. In tomato fruit, Cheniclet et al. (2005) observed that periclinal cell division was completed 5 DAA, whereas other types of cell divisions continued up to 20 DAA. Similar observations were reported by Cong et al. (2002) and Joubès et al. (1999). They showed that the major quantitative trait locus $f w 2.2$, which controls fruit size in tomato, is involved in the regulation of anticlinal and randomly oriented cell divisions but not periclinal cell divisions (Cheniclet et al., 2005; Cong et al., 2002). The regulation of periclinal cell division is not well understood yet.

In our experiment, final pericarp volume was positively correlated with cell number but not with cell volume within each heating treatment (Fig. 5). This suggests that within each heating treatment, variation in pericarp volume was mainly accounted for by cell division. Bertin (2005) found that the size of tomato fruit grown under similar temperature regimes was positively correlated with cell number. The negative correlations noted between cell number and cell volume in our experiment agreed with Bertin's findings and suggest that pericarp cells could be viewed as a population of competing sinks.

\section{Conclusions}

This study aimed at analyzing the response of tomato fruit size to heating as affected by changes in cell number and cell expansion in different directions. Our results showed that reduction in final fruit size of early-heated fruit was mainly associated with reduction in final pericarp cell volume. This study also suggests that in the tomato pericarp, periclinal cell divisions respond differently to temperature than anticlinal and randomly oriented cell divisions. The effects of fruit heating on the time course of cell length and cell width suggest that high temperature reduces expansion in the anticlinal direction more than in the periclinal direction. Our results emphasize the need to measure cell expansion in more than one dimension in histological studies of fruit.

\section{Literature Cited}

Adams, S.R., K.E. Cockshull, and C.R.J. Cave. 2001. Effect of temperature on the growth and development of tomato fruits. Ann. Bot. (Lond.) 88:869-877.

Akashi, T. and H. Shibaoka. 1987. Effects of gibberellin on the arrangement and the cold stability of cortical microtubules in epidermal cells of pea internodes. Plant Cell Physiol. 28:339-348.

Bertin, N. 2005. Analysis of the tomato fruit growth response to temperature and plant fruit load in relation to cell division, cell expansion and DNA endoreduplication. Ann. Bot. (Lond.) 95:439-447. Bohner, J. and F. Bangerth. 1988. Effects of fruit set sequence and defoliation on cell number, cell size and hormone levels of tomato fruits (Lycopersicon esculentum Mill.) within a truss. Plant Growth Regulat. 7:141-155.

Calderón-Zavala, G., A.N. Lakso, and R.M. Piccioni. 2004. Temperature effects on fruit and shoot growth in the apple (Malus domestica) early in the season. Acta Hort. 636:447-453.
Cheniclet, C., W.Y. Rong, M. Causse, N. Frangne, L. Bolling, J.-P. Carde, and J.-P. Renaudin. 2005. Cell expansion and endoreduplication show a large genetic variability in pericarp and contribute strongly to tomato fruit growth. Plant Physiol. 139:1984-1994.

Cong, B., J. Liu, and S.D. Tanksley. 2002. Natural alleles at a tomato fruit size quantitative trait locus differ by heterochronic regulatory mutations. Proc. Natl. Acad. Sci. USA 99:13606-13611.

De Koning, A.N.M. 1989. Development and growth of a commercially grown tomato crop. Acta Hort. 260:267-274.

De Koning, A.N.M. 1994. Development and dry matter distribution in glasshouse tomato: A quantitative approach. $\mathrm{PhD}$ thesis, Wageningen Univ., Wageningen, The Netherlands.

De Koning, A.N.M. 2000. The effect of temperature, fruit load and salinity on development rate of tomato fruit. Acta Hort. 519:85-94.

De Kreij, C., W. Voogt, A.L. van den Bos, and R. Baas. 1997. Voetingsoplossingen gesloten teelt systemen tomaten. Proefstation voor bloemisterij en glasgroente, Naaldwijk. Brochure VG 2.

Erwin, J.E., P. Velguth, and R.D. Heins. 1991. Diurnal variations in temperature affect cellular elongation but not division. HortScience 26:721 (Abstr.).

Gautier, H., A. Rocci, M. Buret, D. Grasselly, and M. Causse. 2005. Fruit load or fruit position alters response to temperature and subsequently cherry tomato quality. J. Sci. Food Agr. 85:1009-1016.

Gillaspy, G., H. Ben-David, and W. Gruissem. 1993. Fruits: A developmental perspective. Plant Cell 5:1439-1451.

Greer, D.H., C. Cirillo, and C.L. Norling. 2003. Temperaturedependence of carbon acquisition and demand in relation to shoot and fruit growth of fruiting kiwifruit (Actinidia deliciosa) vines grown in controlled environments. Funct. Plant Biol. 30:927-937.

Ikeda, T., H. Nonami, T. Fukuyama, and Y. Hashimoto. 1999. Hydraulic contribution in cell elongation of tissue-cultured plants: Growth retardation induced by osmotic and temperature stresses and addition of 2,4-dichlorophenoxyacetic acid and benzylaminopurine. Plant Cell Environ. 22:899-912.

Jackson, D. and B. Coombe. 1966. The growth of apricot fruit. I. Morphological changes during development and the effects of various tree factors. Aust. J. Agr. Res. 17:465-477.

Joubès, J., T.-H. Phan, D. Just, C. Rothan, C. Bergounioux, P. Raymond, and C. Chevalier. 1999. Molecular and biochemical characterization of the involvement of cyclin-dependent kinase A during the early development of tomato fruit. Plant Physiol. 121:857-869.

Marcelis, L.F.M. and L.R.B. Baan Hofman-Eijer. 1993. Effect of temperature on the growth of individual cucumber fruits. Physiol. Plant. 87:321-328.

Pearce, B.D., R.I. Grange, and K. Hardwick. 1993. The growth of young tomato fruit. I. Effects of temperature and irradiance on fruit grown in controlled environments. J. Hort. Sci. 68:1-11.

Prat, S. 2010. Hormonal and daylength control of potato tuberization, p. 574-596. In: Davies, P.J. (ed.). Plant hormones: Biosynthesis, signal transduction, action. Springer, Dordrecht, The Netherlands.

Sasaki, H., T. Yano, and A. Yamasaki. 2005. Reduction of high temperature inhibition in tomato fruit set by plant growth regulators. Jpn. Agr. Res. Qrtly. 39:135-138.

Sawhney, V.K. and P.L. Polowick. 1985. Fruit development in tomato: The role of temperature. Can. J. Bot. 63:1031-1034.

Strøm, M. and R. Moe. 1997. DIF affects internode and cell extension growth and cell number in Campanula isophylla shoots. Acta Hort. 435:17-24.

Van der Ploeg, A. and E. Heuvelink. 2005. Influence of sub-optimal temperature on tomato growth and yield: A review. J. Hort. Sci. Biotechnol. 80:652-659.

Wasteneys, G.O. and J.C. Ambroise. 2009. Spatial organization of plant cortical microtubules: Close encounters of the 2D kind. Trends Cell Biol. 19:62-71.

Wubs, A.M., E. Heuvelink, and L.F.M. Marcelis. 2009. Abortion of reproductive organs in sweet pepper (Capsicum annuum L.): A review. J. Hort. Sci. Biotechnol. 84:467-475. 